\title{
Fine Feathers Make Fine Birds? \\ Wealth Effects and the Choice between Major and Minor Corporate Name Changes ${ }^{\text {t }}$
}

\author{
Patrick Göttner and Peter Limbach ${ }^{*}$ \\ Karlsruhe Institute of Technology (KIT), Department of Banking and Finance
}

Second Draft: January 2011

\begin{abstract}
This study is the first to investigate the causes and effects of corporate name changes in Continental Europe using a sample of German firms in the period 1997-2009. We report a positive and significant stock market reaction to announcements of corporate name changes considerably different for major and minor name changes. Regression results show that prior firm performance positively affects the observed stock returns. Short-term effects turn out to be transitory as firms significantly underperform the German CDAX in the year after the name change was announced. As the first study, we examine the impact of performance and corporate governance on the probability of corporate name changes and show that managers react to poor firm performance by implementing more expensive major name changes. This can be interpreted as an attempt to cloud poor past performance of both the firm and the management. Accordingly, we document a positive relation between management influence, available cash, and the probability of major name changes.
\end{abstract}

Keywords: corporate name changes, corporate governance, event studies, reputation JEL classification: G14, G30, G34

\footnotetext{
We thank Thomas Burdelski, Markus Doumet, Andreea Hannich, Torsten Lüdecke, and seminar participants at Karlsruhe Institute of Technology for helpful discussions. We are especially indebted to Christian Andres, André Betzer, and Martin Ruckes for very insightful comments and discussions. All omissions and errors are our own.

* Corresponding author: Peter Limbach, contact: Karlsruher Institut für Technologie (KIT), Institut für Finanzwirtschaft, Banken und Versicherungen, Abteilung Finanzwirtschaft und Banken, Gebäude 20.13, Kaiserstrasse 12, 76128 Karlsruhe, email: peter.limbach@kit.edu.
} 


\section{Introduction}

„How vain, without the merit, is the name.“

(Homer)

The search for a suitable name of a person, product or company has ever since been an omnipresent issue ${ }^{1}$ that "has managed to capture the interest of such a disparate group of scholars” (Koku 1997, p. 392). As pointed out by Tadelis (1999), the corporate name, as the essence of a firm's identity, usually is the first contact that investors, customers, and other stakeholders have with a firm. With the globalization, competition has not only induced an increased need for distinctiveness among firms but also a restricted availability of a 'perfect name'. The importance and the difficulty of choosing the right name for a company does not only show in the growing number of corporate-name consultancies such as Thomson CompuMark or Naming Names as well as internet naming platforms like 'NameThis' and 'Kluster'. It primarily becomes transparent by the cases of firms that returned to their former name only shortly after adopting a new one: UAL Corp. (operating United Airlines) became 'Allegis' in 1987 and changed back to UAL already in 1988, the British Royal Mail reversed its 2001 name change to 'Consignia' in 2002, and PriceWaterhouseCoopers Consulting (PWC) renamed itself 'Monday' in 2002 quickly changing back to PWC the same year.

Managers do not only have the choice to conduct a name change or not, they choose between the implementation of a major or minor name change. These two types of name-change investments not only differ by the associated costs which are generally higher for major name changes (Horsky and Swyngedouw 1987). Like in the aforementioned examples, major name changes result in adopting completely new and often artificial names that cannot be associated with the old firm. Thus, they are interpretable as the start of a new reputation history for both the firm and the management (as reasoned by Tadelis 1999 and $\mathrm{Wu} 2010$ ). The name change of Andersen Consulting to Accenture around the U.S. accounting scandals in 2001 exemplifies this argument. Minor name changes can be interpreted as managerial commitments to pursue certain strategies, for instance changes in the business focus $(\mathrm{Wu}$ 2010). These strategies can be signaled to stakeholders via inclusions or deletions of suffixes like “.com” (Cooper et al. 2001, 2005) or symbolic terms like “oil” (Yang et al. 2008) or "China” (Bae and Wang 2010). A well known example is the firm Apple which abandoned the word "Computer" from its name with the introduction of the iPhone in January 2007.

\footnotetext{
${ }^{1}$ It ranges from actors' screen names (e.g. Walter Matuschanskavsky became Walter Matthau) and bands ('Long John and the Silver Men’ were renamed The Beatles) to brands (Raider became Twix) and firms.
} 
This study deals with both name changes in general as well as the distinction and choice between major and minor name changes. We provide the first empirical evidence on how variables related to corporate governance and firm performance (i.e. reputation) affect the firms' stock returns in response to name-change announcements and the choice between major and minor name changes. Using most recent data (1997-2009) for Germany, our study highlights the role of reputation and governance in corporate investment decisions in a period of time where picking the right name has become an increasingly advanced corporate investment due to the fact that 'good names get taken early' (Clifford 2001). ${ }^{2}$ Hereby we add to the growing literature on corporate name changes as well as the literature on corporate governance and reputation.

When examining corporate investment decisions and governance, patterns of the firms' ownership structure and investor protection become crucial. Employing German data yields valuable insights due to the reported characteristics and differences of the German (bankbased) corporate governance system as compared to the U.S. and the U.K. (see e.g. Achleitner et al. 2010a). La Porta et al. (2002) state that the degree of equity investor protection in Germany is comparatively low. Furthermore, as reported in Franks and Mayer (2001) and Andres (2007), about 85\% of the quoted companies in Germany have a single shareholder owning more than $25 \%$ of the voting rights (which represents a blocking minority according to the German Stock Corporation Act, AktG). In this study, we conduct the first in-depth examination of corporate name changes in Germany as a different governance system compared to the Anglo-Saxon system for which the vast majority of studies exists.

Corporate name changes are important managerial investment decisions associated with significant costs to corporations. For instance, PWC faced a total bill of \$110 million for marketing campaigns and corporate-name consultancy (Treadwell 2003). The most cited example is Exxon's change from Esso with reported costs of about $\$ 200$ million (McQuade 1984). ${ }^{3}$ A recent example from Germany is Premiere AG changing to Sky Deutschland AG resulting in expenses of more than $€ 330$ million only due to trademark impairments (see Sky Deutschland Annual Report 2009). Besides write downs, expenses for consultants, legal advisors, or marketing, name-change related costs range from the production and design of new logos and staff uniforms as well as printing new stationery and bank forms to the

\footnotetext{
${ }^{2}$ Accordingly, the Office for Harmonization in the Internal Market (2010) reports registered trademarks in the European Union grew at a compound annual growth rate (CAGR) of about $90 \%$ in our sample period. Registrations from Germany account for about $25 \%$ of these trademarks.

${ }^{3}$ Other examples like the amount of $\$ 100$ million for Andersen Consulting becoming Accenture in 2001 (reported in Wu 2010) testify to outstanding costs.
} 
registration of new internet domains and the consumption of significant amounts of management's time.

With all the aforementioned costs a company has to face, name changes must also bring with them some benefits. Evidently, one effect of name changes on corporations is attraction of and recognition by stakeholders. Some of today's global players, like Google (former name 'Backrub') or EBay ('Auction Web’), rose out of anonymity with their new labeling. Accordingly, Karpoff and Rankine (1994) state that many investment analysts claim that investors have preferences for certain types of names. Empirical findings by Cooper et al. (2001) and (2005) lend evidence to this argument. Additionally, Manning et al. (1985) report that $54 \%$ of surveyed analysts stated that a company's name affects its price-earnings ratio.

Predominantly, name changes are considered signaling devices used by corporate management to convey information to stakeholders (Spence 1973, Bergen et al. 1992). ${ }^{4}$ In this sense, a firm's name is changed to convey information to the market, either about changes in the firm's lines of business or as signals of management's private information about the firm's future performance (Karpoff and Rankine 1994). The studies by Cooper et al. (2001 and 2005) reason managers are able to time corporate name changes in order to move the firm's name away from (or into) out-of-favor (in-favor) industries resulting in positive value effects.

Alternatively, name changes by corporations can be understood as investments in intangible assets (i.e. brand name capital or reputation) as argued in several studies (e.g. Tadelis 1999). In this sense, a firm name is considered to be a utility-producing attribute. Name changes can lead to positive changes in market position and identification (Kilic and Dursun 2006). For instance, investments in new names can increase consumer preferences for the firm's products, shift cost functions and demand curves, or improve firm profitability by enhancing employee morale as well as investor and potential employee attraction (see e.g. Horsky and Swyngedouw 1987, Dowling 1988, Fombrun and Shanley 1990, Riordan et al. 1997, Kay 2006). Especially Tadelis (1999) and Dowling (2006) stress the reputational aspect of names. While the former states that the name is one of the strongest representatives of the past performance and corporate characteristics in the stakeholders' mind, the latter claims that corporate reputation is part of the firm's intrinsic value and, thus, incorporated in the firm's stock price (see Einwiller and Will 2002 for empirical evidence).

\footnotetext{
${ }^{4} \mathrm{Wu}(2010)$ argues that name changes are strong signals because they are expensive and, in most cases, only appear once. The author reports that less than $25 \%$ of sample firms conduct repeated name changes.
} 
Earlier empirical work yields ambiguous results on the effects of corporate name changes. While studies initially documented insignificant stock market reactions to announcements of corporate name changes (e.g. Bosch and Hirschey 1989, Karpoff and Rankine 1994), more recent studies report significant positive returns (e.g. Wu 2010, Liu 2010). Hence, wealth effects of corporate name changes remain an unanswered empirical question. Although several news sources reported positive effects of name changes for German and other European firms in the past ${ }^{5}$, neither the German nor other Continental-European markets have been examined yet. More important, general academic evidence on variables that drive namechange decisions and the observed stock returns to name-change announcements is extremely scarce, leading to a rather poor understanding of these corporate events.

This study reports a significant $4.4 \%$ cumulated abnormal return (CAR) for the 20 days prior to the announcement of a name change, in line with previous studies, as well as a significant day-zero abnormal return of $0.3 \%$. Separate examination reveals that firms announcing minor name changes exhibit a negative average stock-price reaction, whereas firms that conduct major name changes show continuous pre-event run-ups and an average CAR of $6.8 \%$ for the overall event window [-20,20]. Results are not driven by internet-related corporate name changes. We document a significant positive relation between prior firm performance and abnormal returns. The firms' largest shareholder's identity (especially family firms) significantly affects the observed stock returns. The documented short-term effects of major name changes turn out to be transitory as both types of name-changing firms significantly underperform the German CDAX in the six and twelve months after the event month. Thus, results point to some degree of investor credulity in the German stock market.

Motivated by the identified differences across the firms in our subsamples, we run binomial logistic regressions on the choice between major and minor name changes. In line with reports in the business press $^{6}$, results suggest that managers instigate major name changes as a reaction to poor firm performance. We report a significant negative relation between a firm's (or management's) performance and the probability of major name changes pointing to the management's incentive to spend firm resources on more expensive major name changes. This is interpretable as an attempt to start a new reputation history - for both the firm and the manager - in order to cloud poor past performance. Results are backed by additional findings

\footnotetext{
${ }^{5}$ The change of German IWKA AG to KUKA AG was accompanied by analyst recommendations and positive stock returns (Reuters on July 9, 2007). Additionally, newspaper 'Neue Züricher Zeitung' on October 7, 2003 featured a report on corporate name changes stating these events result in positive valuation effects.

${ }^{6}$ For instance, German newspaper 'Frankfurter Allgemeine Zeitung' on September 16, 2010 reported former Gericom AG changed to Quanmax AG as the firm’s old name was associated with poor past performance.
} 
documenting a positive relation between the management's influence (i.e. less intensive corporate governance or managerial ownership), available cash and the probability of major name changes.

The remainder of this paper is organized as follows: Section 2 reviews the related literature and presents our hypotheses. Section 3 discusses our data and the applied methodology. Section 4 presents our analyses of the wealth effects of corporate name changes, while Section 5 provides the reader with an analysis of the management's choice between major and minor name changes. Section 6 concludes.

\section{Related Literature and Hypotheses}

\subsection{Related Literature}

The empirical literature on wealth effects of corporate name changes can roughly be separated into two groups, the rationality perspective and the irrationality perspective. An overview of the main studies is provided in Table 1.

[Insert Table 1 about here]

Initially the vast majority of the first group of studies (Howe 1982, Bosch and Hirschey 1989, Karpoff and Rankine 1994) reports an insignificant stock-price reaction to name-change announcements, indicating that these corporate actions are neutral financial or well predictable events. More recent papers, Wu (2010) and Liu (2010), report significant positive announcement effects of about $1.5 \%$ and $1.2 \%$, respectively.

Among this group of studies, Bosch and Hirschey (1989) were the first that separately examined announcements of major and minor name changes and offered empirical indications of considerable differences between these two types of name changes. The authors report that firms announcing major name changes witness an excess return of $2.5 \%$ significant at the $5 \%$ level for the ten days prior to the name-change event, while minor-name-change firms exhibit insignificant returns of $2.1 \%$. They also show that post-event performance is different for these two types of firms. For the ten days following the event, firms that announced minor name changes exhibit significant abnormal returns of $-2.71 \%$ on average compared to insignificant $-0.88 \%$ average abnormal returns for those firms that announced major changes.

Although the studies mentioned above offer mixed evidence on the existence of a significant announcement effect of corporate name changes, almost all investigations document large 
pre-event run-ups ten to thirty days before the event. These findings seem to be compatible with Howe's (1982) conclusion that market participants anticipate firm name changes (see also Karpoff and Rankine 1994). Another common finding is the existence of postannouncement drifts. Bosch and Hirschey (1989) and Liu (2010) report significant cumulated abnormal returns of $-1.86 \%$ and $-1.14 \%$ for the ten and fourty days after the event, respectively. This transitory effect is also reported in Karpoff and Rankine (1994).

The aforementioned results are backed by several non-U.S. studies, for instance Josev et al. (2004) for the Australian market, Karbhari et al. (2004) for Malaysia, Kot and Zhang (2008) for Hong Kong, and Mase (2009) for the United Kingdom.

The second group of studies argues that positive valuation effects of corporate name changes are driven by investor irrationality rather than rational pricing as many name changes appear to be only cosmetic, i.e. not accompanied by any real changes in the firm. The two most prominent studies are Cooper et al. (2001) and Cooper et al. (2005). While the former examine the U.S. stock-market reaction of firms announcing “.com”-inclusions in the years 1998-99, the latter investigate the effect of “.com”-deletions in the period 1998-2001. Cooper et al. (2001) report significant CARs of $18 \%$ on the event and the subsequent day with significant pre-event run-ups of $31 \%$ in the event window $[-15,-2]$. As these returns are similar across all 95 sample firms, no matter if a firm is actually involved in the internet industry, the authors conclude that 'investor mania' must drive these results. For the same event windows, Cooper et al. (2005) document significant CARs of $8 \%$ and $22 \%$ for their sample of 61 firms announcing “.com” deletions. The authors report significantly larger excess returns for firms announcing major name changes. In both studies, the observed stockprice reaction appears to be non-transitory in the short run as cumulated abnormal returns even increase after the event date.

Other papers that belong to this group of studies deal with high-tech sounding firm names (Ferris 1988), fund name changes and inflows (Cooper, Gulen and Rau 2005), oil-related name changes (Yang et al. 2008), and the performance of china-name stocks (Bae and Wang 2010). Results offer further evidence on the existence of investor irrationality in hot markets.

To date, only Wu (2010) has tried to explain the observed stock returns in reaction to namechange announcements. The author reports that brand adoptions have a significantly positive impact on abnormal returns, while radical name changes (unrelated to brands) have no 
explanatory power for abnormal returns. ${ }^{7}$ Variables related to firm performance or corporate governance are not employed. ${ }^{8}$

With respect to long-term performance of name-change firms, only few studies exist. For the United Kingdom, Andrikopoulos et al. (2007) report abnormal returns (to the FTSE All Share Index) of $1.6 \%,-6.8 \%$ and $-13.8 \%$ for the 12,24 and 36 month (respectively) following name-change announcements. For the United States, Lee (2001) reports strongly negative abnormal returns in the year following “.com”-inclusion announcements. For general corporate name changes, Wu (2010) documents significantly negative cumulated abnormal returns in the six and twelve months after the name-change announcement amounting to $8.1 \%$ and $-16.6 \%$, respectively. The latter is the only study that separately investigates the long-term effects of major and minor name changes. The author finds significant returns of $40 \%(-14 \%)$ in the twelve months following announcements of radical name changes (brand adoptions) and significant returns of $-11 \%$ to $-17 \%$ for minor name changes indicating either a broader or a narrower firm focus.

\subsection{Hypotheses}

We refrain from providing a detailed hypotheses section because the existing literature, presented in the previous subsection, yields ambiguous results on the wealth effects of corporate name changes. However, we make the following predictions:

First of all, in line with the literature, we expect overall abnormal returns to name-change announcements to be non-negative and different for major and minor name changes. In this context, we expect returns to be more positive for major name changes due to the "Reputation Start-up Effect” proposed by Tadelis (1999). The author argues that it is easier for good types of firms to build their own name/reputation as it is for the bad types of firms. Hence, the market may interpret announcements of major name changes as credible signals of good firms which are rather capable of (re)building firm reputation. ${ }^{9}$ This is in line with earlier evidence presented in Bosch and Hirschey (1989), Cooper et al. (2005), and Liu (2010).

\footnotetext{
${ }^{7}$ We do not further address this issue as only about $2 \%$ of the firms in our sample announce brand adoptions.

${ }^{8}$ In this context, Liu (2010) reports a significant negative relation between a firm's earnings per share and its abnormal returns to name-change announcements for the event window [-60,40]. However, he does not investigate abnormal returns on or around the announcement day.

${ }^{9}$ The prediction that major name changes lead to larger stock returns is also in line with the fact that major name changes are generally more expensive than minor name changes (and thus more credible signals) and often result in artificial names. In this context, Kohli and Hemnes (1995) conclude the optimal name for a company is an artificial name.
} 
Secondly, we expect firms with better past performance to exhibit larger stock-price reactions to announcements of name changes as investors more likely believe in the managements' skills and ability to select positive-NPV projects. We also expect that firms whose top management owns a stake in the firm's equity exhibit larger stock returns as the managers directly participate from their investment decisions (resulting in more credible signals to investors). With respect to corporate governance, we generally expect a positive relation between the observed stock returns to name-change announcements and the quality (or intensity) of a firm's corporate governance in line with its role to assure managers act in the interest of the firm's shareholders (e.g. Shleifer and Vishny 1997). However, we acknowledge that name changes can also be perceived as good signals by the stock market when announced by less or badly governed firms. Thus, the effect of corporate governance on observed stock returns is an empirical question. The choice of the variables we employ to examine the effect of a firm's governance quality is motivated in the following data section.

\section{Data and Methodology}

\subsection{Data Selection}

To determine our initial sample, we use a list of all corporate name changes implemented by German firms between 1995 and 2009 available in Standard and Poor's Capital IQ database. We check this list with a comparable list of name-change firms available in Bloomberg. Additionally, we screen the annual German Hoppenstedt catalogues for the years of our sample period. Hoppenstedt lists all quoted firms on the German stock market in each year and offers a feature called 'former name' for firms that conducted a name change. We thereby conduct a check of the completeness of our initial sample and account for firms that exhibited a delisting within the sample period. The initial sample consists of more than 200 firms. We then exclude - in line with prior research - all unlisted firms and all firms that changed their name due to a merger or acquisition, or due to a change of only their legal form (e.g. from German AG to European SE). Further, we exclude those firms that only changed their name at the product or subsidiary level. For the remaining events we define the announcement date of a corporate name change as the first date the name change was announced in the LexisNexis database. To make sure we identify the earliest date and, thus, are able to isolate the announcement effect, we also check other publicly available data sources on the internet. ${ }^{10}$ In case we identify an earlier date on the alternative data sources, we define this date as the

\footnotetext{
${ }^{10}$ For instance, we use the web sites of the ,Deutsche Gesellschaft für Ad-hoc Publizität' (www.dgap.de) and the ,Bundesanzeiger' (www.ebundesanzeiger.de) provided by the German Federal Ministry of Law.
} 
announcement date. In a last step, we screen the sample for confounding events such as synchronous earnings announcements, stock splits, share repurchases or M\&A transactions. We are left with a final sample of 69 corporate name changes between 1997 and 2009. ${ }^{11}$

\subsection{Methodology}

\section{Event Studies}

In order to detect the short-term wealth effects of corporate name changes, we employ standard market-model methodology in our event study using an estimation window of 180 trading days that ends 21 trading days prior to the event. The abnormal returns are computed using the German Composite DAX $(\mathrm{CDAX})^{12}$ as our relevant benchmark portfolio. To test whether computed returns are significantly different from zero, we use the Z-statistic (Patell 1976) as well as the BMP-statistic (Boehmer et al. 1991) to account for the potential problems of event clustering and event-induced variance.

In addition, we analyze long-term stock performance surrounding the announcement date via the buy-and-hold approach suggested by Barber and Lyon (1997) and Kothari and Warner (1997). Buy-and-hold abnormal returns (BHARs) are computed relative to the CDAX. ${ }^{13}$ We examine the period of one year before to one year after the month when the name change was first announced. Analytically, the excess performance of our name-changing firms, measured with BHARs, is calculated as:

$$
B H A R_{i, k}=\left[\prod_{t=1}^{k}\left[\left(1+r_{i, t}\right)\right]-1\right]-\left[\prod_{t=1}^{k}\left[\left(1+r_{M, t}\right)\right]-1\right]
$$

where i stands for firm i, $\mathrm{r}$ is the raw return, $\mathrm{M}$ stands for the market portfolio, $\mathrm{t}$ denotes the month, and $\mathrm{k}$ denotes the $\mathrm{k}$-months holding period.

The average buy-and-hold abnormal returns (ABHARs) for $\mathrm{N}$ securities and a holding period of $\mathrm{k}$ months are estimated in the following way:

$$
A B H A R_{N, k}=\frac{1}{N} \sum_{i=1}^{N} B H A R_{i, k}
$$

\footnotetext{
${ }^{11}$ Other studies (e.g. Bosch and Hirschey 1989, Wu 2010) also report reductions of $60 \%$ or more of their initial sample size. In fact, most studies (e.g. Howe 1982, Horsky and Swyngedouw 1987, Karpoff and Rankine 1994, Cooper et al. 2001 and 2005) examine final samples comprising about 50 to 100 events.

${ }^{12}$ The CDAX is the broadest German stock index. It contains all German firms listed in the 'General Standard' and 'Prime Standard' of the Frankfurt Stock Exchange. For more information, see www.deutsche-boerse.com.

${ }^{13}$ We explicitly employ the long-term study to complement and assess our short-term findings. Hence, we do not employ more sophisticated matching approaches as in Karpoff et al. (1996), for instance.
} 
Data on stock prices is provided by the 'Karlsruher Kapitalmarktdatenbank' (KKMDB) which receives its data directly from the Frankfurt Stock Exchange (Deutsche Boerse AG).

\section{Binomial Logit Regressions}

Running logistic regressions, we further investigate how firm characteristics, such as prior performance or corporate governance, affect the probability of major name changes. The methodology we employ consists of the following binomial logit:

$$
L_{i}=\ln \left(\frac{P_{i}}{1-P_{i}}\right)=Z_{i}
$$

In the logit the dependent variable is set to one if the firm conducts a major name change and zero otherwise (i.e. for minor name changes).

\subsection{Employed Variables and Descriptive Statistics}

We distinguish firms that conduct major name changes from those that conduct minor name changes. In doing so, we use the definition of Bosch and Hirschey (1989) who initially examined these two groups of name-changing firms. Major name changes are those name changes where the new name is entirely different from the old one, e.g. Karstadt Quelle AG versus Arcandor AG. ${ }^{14}$ Minor name changes do not completely affect firm recognition, e.g. $\mathrm{D}+\mathrm{S}$ online AG versus D+S Europe AG.

Following Koku (1997), we use an indicator variable service firm which obtains a value of one for those firms which do not produce goods, for instance firms offering financial services. This is due to the fact that the signalled changes of these firms generally cannot be verified as easily as for manufacturing firms where changes in product quality can be examined in a shorter period of time. In line with Wu (2010), we control for CEO turnover prior to the announcement of the name change. We assign a value of one to the indicator variable CEO turnover if the chairman of the board changed in the year the name change was announced or the year before. Further, we control for firms with family names employing an indicator variable which is set to one if the firm has a family name prior to the name change. Signals may be different for family firms due to the reported differences with respect to firm performance, corporate governance, and the cost of debt (see e.g. Anderson and Reeb 2003,

\footnotetext{
${ }^{14}$ This also exemplifies our definition of artificial name changes. Artificial names do not have a direct meaning, they are artificial on linguistic grounds. Thus, artificial names are a subcategory of major name changes.
} 
Anderson et al. 2003 as well as Andres 2008 for German evidence). A name change where a family name is abolished may be a stronger signal of future changes in the firm's course. ${ }^{15}$

As measures of firm/management performance, we use the return on assets (ROA) and free cash flow - defined as net income plus depreciation and amortization - as a percentage of total assets (FCF). Additionally, we employ the indicator variables FCF negative and earnings negative that obtain a value of one if the firm's free cash flow or net income (respectively) is negative. Comparable performance variables are used in Köke (2004). ${ }^{16}$ We further control for market-based performance using the relative performance of the firms' stock (comparable to Wu 2010) in the six months prior to the event month.

To measure managerial influence and governance quality, we employ the following variables: First, in line with recent theoretical studies demonstrating that multiple blockholders improve a firm's governance (Edmans and Manso 2010, Edmans 2009), we use the number of blockholders as a measure for governance quality. Blockholders are those shareholders owning at least a 5\% block of shares (e.g. Kim 2010). According empirical evidence for Europe shows that the number of blockholders improves a firm's governance (Attig et al. 2008). In another context, McCahery and Schwienbacher (2010) also measure a firm's monitoring intensity by the number of blockholders. As a second and third variable, we employ the Herfindahl index to measure a firm's ownership concentration and we control for the size of the largest shareholder as measured by the amount of the largest share block (Köke 2004, Goergen and Renneboog 2001). Accordingly, Achleitner et al. (2010b) measure large blockholders' incentives to monitor the management by their ownership stake and argue there exists a positive relation between the degree of monitoring conducted by this large shareholder and its own wealth invested in the firm. Concentrated share ownership can overcome the classical free-rider problem (Shleifer and Vishny 1986) and enhance governance quality as large shareholders have incentives to monitor the firm's management because their benefits from monitoring exceed their costs. Thus, firms with more concentrated ownership should exhibit fewer agency problems (Köke 2004).

To account for incentive realignment between shareholders and the management, we primarily employ the variable managerial ownership measured by the amount of voting rights held by the firm's board (e.g. Renneboog et al. 2007). We also control for the squared amount of the voting rights held by the board as earlier empirical studies suggest that high managerial

\footnotetext{
15 We note that only one of these family-name firms in our sample abolished its name due to a change in control.

${ }^{16}$ Köke (2004) also uses an indicator variable ‘Earnings loss’ (i.e. negative EBITDA) as a performance variable.
} 
ownership has a negative effect on firm performance (see e.g. Morck et al. 1988 and McConnell and Servaes 1990 for the U.S. and Weir et al. 2002 for the U.K.).

Finally, we examine the impact of the firms' largest shareholder's identity (LS) on the observed stock returns. ${ }^{17}$ Thereby, we distinguish between families, corporations, institutional investors (e.g. banks, insurance or investment companies), private equity investors (including venture capitalists), the firm's management, and others (e.g. foreign investors or employees). Our classification is in line with Kim (2010) and Renneboog et al. (2007).

Table 2 provides an overview of the sample firms' characteristics. All firm data refers to the fiscal year prior to the name-change announcement. Data is gathered from the Hoppenstedt database and checked via Capital IQ.

[Insert Table 2 about here]

Table 3 contains a list of all variables used in the empirical analysis as well as a detailed definition.

[Insert Table 3 about here]

\section{Wealth Effects of Corporate Name Changes}

\subsection{Short-Term Wealth Effects}

We document a significant abnormal return of $0.33 \%$ on the announcement date (day zero) and significant pre-event run-ups of $4.4 \%$ for the event window [-20,0] in line with the literature (e.g. Bosch and Hirschey 1989, Karpoff and Rankine 1994, Cooper et al. 2001, and Liu 2010) and our prediction in Section 2. For the overall event window [-20,20], we report a significant 2.8\% cumulated abnormal return. Results are presented in Table 4.

[Insert Table 4 about here]

Separate investigation of the short-term wealth effects of major and minor name changes reveals that firms conducting minor name changes do not exhibit pre-event run-ups, while firms that conduct major name changes show continuous pre-event and post-event (!) run-ups. Firms announcing minor name changes exhibit a significant negative market reaction with

\footnotetext{
${ }^{17}$ Following Achleitner et al. (2010b), we also examine the impact of the controlling shareholder's identity (CS) on the firms' observed stock returns.
} 
cumulated abnormal returns of $-4.6 \%$ in the event window $[0,10]$ which remain at this level ( $-4.7 \%$ for the 20 days after the event), while pre-event CARs amount to an insignificant 2.5\% for the 20 days prior to the announcement. Those firms announcing major name changes exhibit CARs of 5.8\% in the event window $[-20,0]$ and $3.0 \%$ in the event window $[0,10]$, both significantly larger than zero. For the overall event window, major-name-change firms have CARs amounting to $6.8 \%$, while firms announcing minor name changes exhibit CARs of $-2.5 \%$ on average. Thus, the findings corroborate our prediction on the different effects of major and minor name changes and are in line with prior work (e.g. Bosch and Hirschey 1989, Cooper et al. 2005). The results are illustrated in Figure 1.

\section{[Insert Figure 1 about here]}

The phenomenon of pre-event stock-price reactions reported in almost all of the previous studies (see Section 2) is also found in our study. These run-ups appear so frequently that it is rather implausible that most researchers, so far, have failed to identify the exact announcement date. Like in this study, these run-ups generally appear about ten to thirty days prior to the announcement. This is little of a surprise as changing a firm's name is not an adhoc decision. It needs thorough planning and preparation that takes place many weeks in advance. We believe that at least some firms communicate their name change in advance to their clients, customers, and other stakeholders to avoid potential confusion. This reasoning also explains why pre-event run-ups are rather a phenomenon of major name changes (e.g. Cooper et al. 2005, Liu 2010) where planning and preparation is of particular importance.

\subsection{Long-Term Wealth Effects}

To give a more comprehensive picture of stock market reactions to corporate name changes, we further investigate the long-term stock performance (relative to the German CDAX) surrounding these corporate actions. As some name changes were announced relatively recently (2008 and 2009) and because a few firms changed their name within their first or second year of being public, we only investigate the one-year stock-price performance symmetrically surrounding the event month. Results are summarized in Table 5.

\section{[Insert Table 5 about here]}

Our findings indicate a large negative post-event and overall performance that is significantly different from zero. We document ABHARs of $-15.8 \%$ and $-16.4 \%$ for the six and twelve 
months, respectively, after the month of the name-change announcement. ${ }^{18}$ For the six months before the name-change announcement, abnormal returns are insignificant and around zero. Hence, results for the German stock market are in line with previous studies, especially $\mathrm{Wu}$ (2010) for the United States. To account for outliers and as a robustness check, we recalculate abnormal returns using a winsorization approach. ${ }^{19}$ Results (not reported for brevity) remain significant and even become more negative. We also check the sample for firms that run into bankruptcy at some point in time after the announced name change. This is the case for five of our sample firms. None of these firms become bankrupt in the year after the announcement.

From the results found in both the short and long-term studies, we can (on average) draw the following conclusions about corporate name changes: Firstly, name-change investments appear to have no (direct or mid-term) positive effect on firm value - in terms of relative stock-price performance, firms perform very poorly in the year after the name-change announcement. Secondly, positive short-term effects appear to be transitory. These findings are in line with the results of Andrikopoulos et al. (2007) for the U.K. Like in our study, the authors report that stock prices peak around the announcement of a name change with the relative stock performance of name-change firms being poor before and after the event month. Figure 2 illustrates the different wealth effects of firms conducting major name changes versus minor name changes. For illustrative means, cumulated monthly ABHARs are shown.

\section{[Insert Figure 2 about here]}

While both types of name changes result in almost equal significant six-month ABHARs of $-16 \%$ (major) and $-15 \%$ (minor) in the period after the event month, firms conducting major name changes exhibit more negative (post-event) twelve-month ABHARs of -19.5\% compared to $-12.5 \%$ for those firms that implement minor name changes.

Comparing long and short-term effects, we can conclude that the announcement of major name changes appears to be good news to the stock market while minor name changes do not. As the relative stock performance of major-name-change firms is very positive in the short run (in line with the "Reputation Start-up Effect”) but strongly negative in the long run (in

\footnotetext{
${ }^{18}$ For reasons such as confounding events we cannot include all 69 event firms in all of our calculations due to missing data or contamination. However, for all windows we use more than 60 firms to calculate ABHARs.

${ }^{19}$ The winsorization approach sets a limit on how far away from the rest of the sample an extreme observation is allowed to be (as the limit we use the fourfold standard deviation of the firms' stock returns). More extreme observations are set equal to this limit, giving the most extreme observations a lower weight without removing them from the sample. Cowan and Sergeant (2001) show this procedure yields correct specifications in case the data suffer a skewness bias described by Barber and Lyon (1997).
} 
line with management's leeway in building up reputation), we present evidence on investor credulity in the German stock market.

\subsection{Explaining Abnormal Returns}

In a next step, we investigate which firm characteristics explain the observed stock market reaction described in subsection 4.1. Therefore, we estimate the following basic equation using the method of ordinary least squares (OLS): ${ }^{20}$

$$
\begin{array}{r}
\mathrm{AR}_{\mathrm{i}}=\mathrm{c}_{0}+\mathrm{c}_{1} \text { service } \text { firm }_{i}+\mathrm{c}_{2} \text { family name }_{i}+\mathrm{c}_{3} \text { log total assets }{ }_{i}+\mathrm{c}_{4} \text { major }_{i} \\
+\ldots \text { governance measures... }+\ldots \text { performance measures } \ldots+\mathrm{e}_{\mathrm{i}}
\end{array}
$$

Tests for heteroscedasticity show that there is heteroscedasticity in the residuals. To avoid this problem we use White's (1980) heteroscedasticity-consistent covariance matrix estimator in order to obtain unbiased estimates of the coefficient covariances. ${ }^{21}$ No evidence can be found for multicollinearity between the independent variables. ${ }^{22}$ The results of our OLS regressions are presented in Table 6.

[Insert Table 6 about here]

\section{The Impact of Prior Performance on Abnormal Returns}

The results of our regression analysis indicate a significant positive relation between day-zero returns and prior firm (or management) performance as measured by free cash flow to total assets (FCF) and return on assets (ROA). While the regression coefficients of the variable FCF are significant at the $1 \%$ level in all regressions (model 1 and models 3-5), the coefficients of the variable ROA are significant at the 10\% (model 2) and 5\% level (model 6), respectively. Hence, we find support for our prediction that firms with better prior performance witness larger returns when announcing a name change (see Section 2.2). Comparing models 1 and 2 as well as models 5 and 6 , the values of the adjusted $\mathrm{R}^{2}$ and especially the F-statistic suggest that the variable FCF more appropriately explains the observed stock returns than the ROA. Employing the indicator variable 'FCF negative' or the ratio of net income to total sales instead of FCF or ROA, the resulting regression coefficients

\footnotetext{
${ }^{20}$ We add additional controls for a firm's available cash and prior CEO turnover in some reported regressions.

${ }^{21}$ Tests for heteroscedasticity were conducted using the White Heteroscedasticity Test (without cross-terms). The test statistic of almost all models lies above the 0.05-critical Chi-Square value.

${ }^{22}$ The absence of multicollinearity can be supported by looking at the pairwise correlation matrix of the explanatory variables (see Table 8). There are no high pairwise correlations among the independent variables employed in each of the regressions. Variance inflation factors are below critical values in all regression models.
} 
are near to zero and insignificant. We also examine the impact of prior stock performance ${ }^{23}$ on the observed returns. The coefficient of this variable is slightly negative and insignificant (not reported for brevity).

\section{The Impact of Corporate Governance on Abnormal Returns}

In models 3-6, we examine the impact of several corporate governance variables on the observed stock market reaction of the firms in our sample. First of all, the number of blockholders, the Herfindahl index, the size of the largest shareholder as well as managerial ownership appear to have no explanatory power for the observed stock returns, neither from a statistical point of view nor from an economic one. Also the squared value of management's voting rights appears to be insignificant (not reported for brevity). Thus, we find no support for our predictions made in the hypotheses section.

However, we find evidence that investors care for the name-changing firms' largest shareholder's identity. We report significant positive abnormal returns for firms de facto controlled by families (significant at the 5\% level in model 5 and at the $1 \%$ level in model 6), institutional investors, other corporations, and the management (each significant at the $10 \%$ level in model 5 and at 5\% level in model 6). Although, due the sample size, one has to be careful when trying to interpret this finding, it points to the idea that the stock market rather believes the name-change investment is profitable (or sustainable) when the firm is controlled by a shareholder with a longer investment horizon. Furthermore, the adjusted $\mathrm{R}^{2}$ is roughly doubled (compared to models 1-3) when we control for shareholder identity (while the Fstatistics remain significant) suggesting that the identity of the firm's largest shareholder has explanatory power for the observed stock returns of name-changing firms. When we examine the impact of the firms' controlling shareholder's identity instead, all of the according regression coefficients remain their signs but are statistically insignificant (not reported).

Finally, the coefficient of the indicator variable 'family name' (for firms that abolish their family name through a name change) is negative in all regression models and even significant at the $5 \%$ level in models 5 and 6 suggesting that family names are valuable brands. The finding is also in line with the idea that the abolition of a family name may signal fewer (or even discontinued) governance by the according family.

\footnotetext{
${ }^{23}$ We measure prior stock performance as the BHARs (relative to the German CDAX) in the six months before the event month.
} 
The results found in the different regression models remain qualitatively unchanged when we control for year or industry effects, firm age or leverage, as well as firms that operate in the internet business ${ }^{24}$. The findings on the firms' largest shareholder's identity do only hold for the ‘LS_Family’ dummy when we control for industry effects (not reported for brevity).

\section{Major versus Minor Name Changes}

From our findings in the last section and the evidence documented in previous studies, we conclude that empirical examinations which do not distinguish between major and minor name changes may not only lack an important detail in their analyses of wealth effects of corporate name changes but may also draw misleading conclusions from the overall results. Major name changes can be considered a different type of investment with respect to the associated costs (e.g. more advertisement or more potential revenue loss). So, when managers decide to change their firm's name, why do some managers choose to implement the costly major name changes while others prefer minor name changes instead?

A major name change can be viewed as the start of a new reputation history (Tadelis 1999 and Wu 2010), especially as many of these name changes are artificial name changes in which names are implemented that can only hardly be associated with the original firm or any direct meaning at all. ${ }^{25}$ The new reputation that starts with a major name change is not only the firm's but also the management's reputation, an important fact not considered in earlier empirical work. We hypothesize a firm's management can be incentivized to spend firm resources (such as available cash) in order to change the firm's name even if this does not necessarily increase shareholder value, but change management's reputation by clouding past performance. ${ }^{26} \mathrm{Wu}$ (2010) offers empirical evidence of the existence of a negative relation

\footnotetext{
${ }^{24}$ These internet-related corporate name changes, that account for $7 \%$ of the events in our sample, significantly reduce day-zero stock returns at the $5 \%$ level in models $1-3$. However, this finding is driven by an outlier. Exclusion of this outlier yields an insignificant effect of the 'internet business' indicator variable.

${ }^{25}$ Accordingly, Cooper et al. (2005) state that ,,[...] it is possible that investors view the firm with a major name change as a potentially 'new firm' [...]” (p. 329).

Recent anecdotal evidence supports this idea: the Financial Times, in its German edition on September 24, 2010, reports that in about 20 cases of stock market manipulation in Germany the names of penny-stocks were intentionally changed in order to subsequently push stock prices by spreading false information.

${ }^{26}$ This strategy can be valuable for the manager when it increases the value of its outside option in the job market, keeps him from being fired, or enables him to reduce his effort. Even new managers who are not responsible for the past performance may want to start a new reputation history in order not to be associated with the firm's old name and/or poor performance. For instance, Thomas Middelhoff was appointed the new CEO of Karstadt Quelle AG in May 2005 - within the following year the firm first announced to plan a name change. To make sure our reasoning holds and name changes are not, indeed, driven by new CEOs, we control for CEO turnover prior to name-change announcements.
} 
between accounting-based firm performance and the probability of both radical and general corporate name changes. ${ }^{27}$

To test whether the aforementioned reasoning holds for "new-reputation” name changes and to understand how past performance and corporate governance influence the name-change decision, we run several binary logistic regressions. ${ }^{28}$ Results indicate which factors drive the probability of a major name change. Table 7 summarizes our main results.

[Insert Table 7 about here]

\section{The Impact of Prior Performance on the Probability of Major Name Changes}

To examine whether managers spend their firms' resources to implement name changes for reputational reasons, we employ several variables as proxies for firm/management performance, namely the return on assets (ROA), the free cash flow to total assets (FCF), and two indicator variables 'FCF negative' and 'earnings negative'. ${ }^{29}$ The results of our binary logistic regressions indicate that managers react to poor firm performance (and hence their own poor performance in case they were in charge of the firm in the past) by implementing major (rather than minor) name changes. The regression coefficients of the indicator variable 'FCF negative' are largely positive and statistically significant at the $5 \%$ level in models 1,2 and 4. The same holds for the coefficient of the indicator variable 'earnings negative' in model 5. Accordingly, computing marginal effects (with all variables at their means), we find that the 'FCF negative' dummy significantly increases the probability of a major name change by $31 \%$ (model 1 ) to $39 \%$ (model 4 ) and the 'earnings negative' dummy by $32 \%$. In regression model 3 the coefficient of the variable ROA is considerably negative indicating a lower probability of a major name change with increasing firm performance. The same holds for the variable FCF, free cash flow to total sales, or net income to total sales (not reported for brevity). However, the regression coefficients of these variables are not statistically significant on conventional levels. We also control for the effect of prior stock performance

\footnotetext{
${ }^{27}$ However, $\mathrm{Wu}$ (2010) does not directly investigate the management's choice between major and minor corporate name changes. The author, within the group of major name changes, compares radical name changes to brand adoptions as the reference group.

${ }^{28}$ In a first step prior to these examinations, we run binary logistic regressions to find out which variables drive a firm's overall probability of conducting a name change (not reported for brevity). The control group in these regressions consists of a sample of 69 matched German firms that have not changed their name. We use the following matching criteria: book value of total assets, SIC code, stock quotation, no M\&A deals. We do not find that any of our employed variables significantly drive the overall name-change probability.

${ }^{29}$ Fombrun and Shanley (1990) and Wu (2010) reason there exists a positive relation between a firm's performance or past accounting profitability and its reputation. See also Tadelis (1999) and Cabral (2000). McGuire et al. (1988), for instance, show that return on assets is highly correlated with a firm's reputation.
} 
on the probability of a major name change. The coefficient is positive but not statistically significant on conventional levels.

\section{The Impact of Corporate Governance on the Probability of Major Name Changes}

In the regression models 2-6 we examine the role of corporate governance on the probability of major name changes. Our results indicate there exists a positive relation between the management's influence and the probability of major name changes. First, we document a positive relation between managerial participation and the probability of major name changes. The regression coefficients of both variables 'managerial ownership' and 'LS_Management' (indicating that the management is the largest shareholder) are largely positive throughout all regressions. The latter is significant at the $10 \%$ level in model 6 . Secondly, the number of blockholders and the Herfindahl index exhibit negative coefficients in all regression models, with the former being statistically significant at the $5 \%$ level in model 4 as well as at the $10 \%$ level in models 2, 3 and 5 . The effect of the number of blockholders remains significant on a statistical basis when we control for the existence of multiple large shareholders or for majority shareholders (not reported). ${ }^{30}$ Our findings are in line with the suggestions made in the literature and Fombrun and Shanley's (1990) conclusion that a firm's reputation is increasing in the number of blockholders. Comparing models 1 and 2, for instance, reveals that the inclusion of governance-related variables almost doubles the $\mathrm{R}^{2}$ and also enhances the overall quality of the model (as the p-value of the Wald-statistic is significantly lowered). Thus, variables that measure the quality or intensity of a firm's governance seem to do well in explaining the management's choice of a name change.

In the regression models 1-3 the coefficient of the variable 'cash' is largely positive and even significant at the $10 \%$ level in model 6 (at the $15 \%$ level in model 1). This indicates a positive relation between available cash and the probability of a major name change. The finding further backs the idea that corporate managers spend their firm's resources to change names and cloud past performance. If this cash could be spent more efficiently, name changes may be interpreted as some kind of investment distortion caused by reputational concerns.

Furthermore, in all performed regressions the coefficients of the variables 'log total assets' and 'family name' are negative implying that major name changes are less probable for larger

\footnotetext{
${ }^{30}$ The indicator variable multiple large shareholders $(M L S)$ is set to one for firms with multiple shareholders with at least $10 \%$ of the shares, and zero otherwise (similar to Attig et al. 2008). When we control for MLS in regression model 1 , for instance, the according coefficient is negative and significant at the $10 \%$ level. The indicator variable majority shareholder is set to one for firms with a shareholder controlling more than 50\% of the firm's common shares, and zero otherwise (similar to Goergen and Renneboog 2010).
} 
firms and firms with family names. The regression coefficients of the latter variable are significant at the $10 \%$ level in model 6. Computing marginal effects (again with all variables at their means), firms with family names have a lower major-name-change probability of 33\% (models 1, 3 and 4) to $41 \%$ (model 2) in line with our reasoning. The coefficient for 'CEO turnover' is positive throughout the models 1-6 suggesting that new CEOs tend to change their firms’ name radically in line with our reasoning.

In other regressions (not reported for brevity) we control for internet-related name changes, firm age, leverage, year or industry effects as well as the controlling shareholder's identity. Results remain qualitatively unchanged.

\section{Conclusion}

By investigating the German market, this study provides the first empirical evidence on wealth effects of corporate name changes in Continental Europe as a different corporategovernance system compared to the Anglo-Saxon countries. Results suggest there are significant differences between those firms announcing major and those announcing minor name changes. While the former exhibit transitory positive abnormal returns, for the latter a name-change announcement seems to be no good signal to the stock market. Different valuation effects for these two groups (i.e. netting out) may account for the abnormal returns near to zero documented in the early studies where only Bosch and Hirschey (1989) made the major-minor distinction. Our study is the first to investigate the impact of firm performance and corporate governance on the observed stock returns and the management's decision to implement a major or a minor corporate name change. Results offer evidence that market participants regard name changes as corporate investment decisions. We find a positive and significant relation between prior firm performance and stock returns. Furthermore, the identity of the firm's largest (i.e. de facto controlling) shareholder seems to matter to stockmarket investors. Our results indicate that especially firms controlled by families witness positive stock returns to name-change announcements. This corroborates prior findings that family-controlled firms make better investment decisions. Accordingly, we document that family-name abolitions result in negative stock returns. With respect to long-term effects of corporate name changes, our study documents an average stock-price peak around the event month similar to findings for the U.K. Post-event stock performance is considerably poor with both types of firms underperforming the German CDAX in the year after the announcement of the name change. 
Additionally, this paper provides an analysis of the management's choice between major and minor corporate name changes motivated by the differences found in the wealth-effect analyses and the earlier literature. Our results suggest that managers instigate more expensive major (radical) name changes to disassociate with poor past performance. This finding seems logical because the worse a firm's/manager's performance (i.e. reputation), the less the firm/manager will have to lose from abandoning the old firm name in order to start a new reputation history. The reputational restart leaves the manager with leeway on actively building up a new reputation or not. This is in line with the fact that radical name changes signify managerial activity that can only hardly be comprehended, whereas minor name changes such as inclusions or deletions (e.g. of business focusing or broadening), signal a certain strategy to be pursued in the future, i.e. a direct managerial obligation. Of course, we cannot tell for sure whether managers conduct these name changes to help their firm or just to rebuild their own reputation (or both). However, results advert to the idea that managers are tempted to spend their firm's resources to start their own new reputation history even if it does not help the firm in the long run as the results of our long-term event study indicate. In this context, we show that the probability of major name changes is driven by the firm's available cash. Accordingly, additional findings show that enhanced managerial influence increases the aforementioned problem, supporting the idea of new reputation build-ups by the corporate management. However, we show that enhanced corporate governance (reducing management's leeway) mitigates this problem.

Overall, our results confirm the opinion of many economists that the market believes a firm with a completely new name is a new firm (Cooper et al. 2005, Wu 2010) and that major name changes can be interpreted as means of obfuscation by the corporate management. Managers who are aware of this apparent market irrationality can rationally implement major name changes for both reputational and cosmetic reasons. Our findings on major name changes in particular point to some degree of investor credulity or even irrationality and thereby especially lend evidence to the irrationality perspective on corporate name changes.

We believe future research should deal with the exact costs as well as the choice between major and minor name changes. We find it plausible that major name changes are a form of investment distortion that stems from reputational incentives of corporate managers. In this context, it further seems worth investigating the stock-price reactions to first-time versus repeated and reverse corporate name changes. 


\section{References}

Achleitner, A.-K., C. Andres, A. Betzer, and C. Weir (2010): Economic Consequences of Private Equity Investments on the German Stock Market, European Journal of Finance, Forthcoming.

Achleitner, A.-K., A. Betzer, M. Goergen and B. Hinterramskogler (2010): Private Equity Acquisitions of Continental European Firms - The Impact of Ownership and Control on the Likelihood of Being Taken Private, European Financial Management, Forthcoming.

Andersen, R.C. and D.M. Reeb (2003): Founding Family Ownership and Firm Performance: Evidenve from the S\&P 500, Journal of Finance 58, 1301-1328.

Andersen, R.C., S.A. Mansi and D.M. Reeb (2003): Founding Family Ownership and the Agency Cost of Debt, Journal of Financial Economics 68, 263-285.

Andres, C. (2008): Large Shareholders and Firm Performance - An Empirical Examination of Founding-Family Ownership, Journal of Corporate Finance 14, 431-445.

Andres, C. (2007): Family Ownership, Financing Constraints and Investment Decisions, Working Paper University of Bonn.

Andrikopoulos, P., A. Daynes and P. Pagas (2007): The Long-Term Market Performance of UK Companies Following Corporate Name Changes, Working Paper University of Portsmouth.

Attig, N., O. Guedhami and D. Mishra (2008): Multiple Large Shareholders, Control Contests, and Implied Cost of Equity, Journal of Corporate Finance 14, 721-737.

Bae, K.-H. and W. Wang (2010): What's in a "China” Name? A Test of Investor Sentiment Hypothesis, Working Paper York University, Schulich School of Business.

Barber, B.M. and J.D. Lyon (1997): Detecting Long-Run Abnormal Stock Returns: The Empirical Power and Specification of Test Statistics, Journal of Financial Economics 43, 341-372.

Bergen, M., S. Dutta and C.O. Walker (1992): Agency Relationships in Marketing: A Review of the Implications and Applications of Agency and Related Theories, Journal of Marketing 56, 1-24.

Boehmer, E., J. Musumeci and A.B. Poulsen (1991): Event-Study Methodology under Conditions of Event-Induced Variance, Journal of Financial Economics 30, 253-272.

Bosch, J.-C. and M. Hirschey (1989): The Valuation Effects of Corporate Name Changes, Financial Management 18, 64-73.

Cabral, L.M.B. (2000): Stretching Firm and Brand Reputation, Rand Journal of Economics 31, 658-673. 
Clifford, L. (2001): What's In A (Hip, New) Name?, Fortune Magazine, April 16, 2001.

Cooper, M.J., O. Dimitrov and P.R. Rau (2001): A Rose.com by Any Other Name, Journal of Finance 56, 2371-2388.

Cooper, M.J., A. Khorana, I. Osobov, A. Patel and P.R. Rau (2005): Managerial Actions in Response to a Downturn: Valuation Effects of Name Changes in the dot.com Decline, Journal of Corporate Finance 11, 319-335.

Cooper, M.J., H. Gulen and P.R. Rau (2005): Changing Names with Style: Mutual Fund Name Changes and Their Effect on Fund Flows, Journal of Finance 60, 2825-2858.

Cowan, A.R. and A.M.A. Sergeant (2001): Interacting biases, non-normal return distributions and the performance of tests for long-horizon event studies, Journal of Banking and Finance 25, 741-765.

Dowling, G. (1988): Measuring Corporate Images: A Review of Alternative Approaches, Journal of Business Research 17, 27-34.

Dowling, G. (2006): How Good Corporate Reputations Create Corporate Value, Corporate Reputation Review 9, 134-143.

Edmans, A. (2009): Blockholder Trading, Market Efficiency, and Managerial Myopia, Journal of Finance 64, 2481-2513.

Edmans, A. and G. Manso (2010): Governance Through Trading and Intervention: A Theory of Multiple Blockholders, Working Paper University of Pennsylvania, The Wharton School.

Einwiller, S. and M. Will (2002): Towards an Integrated Approach to Corporate Branding An Empirical Study, Corporate Communications 7, 100-109.

Ferris, S.P. (1988): The Effect of Corporate Name Changes on Shareholder Wealth, Journal of Applied Business Research 4, 40-49.

Franks, J. and C. Mayer (2001): Ownership and Control of German Corporations, Review of Financial Studies 14, 943-977.

Fombrun, C. and M. Shanley (1990): What's in a Name? Reputation Building and Corporate Strategy, The Academy of Management Journal 33, 233-258.

Goergen, M. and L. Renneboog (2010): The Social Responsibility of Major Shareholders, in: G. Aras and D. Crowther (eds.): The Gower Handbook of Corporate Governance and Social Responsibility, Gower Publishers, 2010, 287-307.

Goergen, M. and L. Renneboog (2001): Investment Policy, Internal Financing and Ownership Concentration in the UK, Journal of Corporate Finance 7, 257-284. 
Horsky, D. and P. Swyngedouw (1987): Does It Pay to Change Your Company's Name? A Stock Market Perspective, Marketing Science 6, 320-335.

Howe, J. (1982): A Rose by Any Other Name? A Note on Corporate Name Changes, Financial Review 17, 271-278.

Josev, T., C. Howard and R. Faff (2004): What's in a Name? Evidence on Corporate Name Changes from the Australian Capital Market, Pacific Accounting Review 16, 57-76.

Karbhari, Y., Z. Sori and S. Mohamad (2004): Shareholder Wealth Effects and Corporate Name Changes: Evidence from Malaysia, Corporate Ownership and Control 2, 38-49.

Karpoff, J. and G. Rankine (1994): In Search of a Signaling Effect: The Wealth Effects of Corporate Name Changes, Journal of Banking and Finance 18, 1027-1045.

Karpoff, J., P.H. Malatesta and R.A. Walking (1996): Corporate Governance and Shareholder Initiatives: Empirical Evidence, Journal of Financial Economics 42, 365-395.

Kay, M. (2006): Strong Brands and Corporate Brands, European Journal of Marketing 40, 742-760.

Kilic, C. and T. Dursun (2006): The Effect of Corporate Identity Changes on Firm Value: An Empirical Investigation, Journal of the American Academy of Business 10, 234-240.

Kim, K. (2010): Blockholder Monitoring and the Efficiency of Pay-Performance Benchmarking, Journal of Corporate Finance 16, 748-766.

Kohli, C. and T.M. Hemnes (1995): A Corporation By Any Other Name...?, Business Horizons, November-December 1995.

Köke, J. (2004): The Market for Corporate Control in a Bank-Based Economy: A Governance Device?, Journal of Corporate Finance 10, 53-80.

Koku, P.S. (1997): Corporate Name Change Signaling in the Services Industry, Journal of Services Marketing 11, 392-408.

Kothari, S.P. and J.B. Warner (1997): Measuring Long-Horizon Security Price Performance, Journal of Financial Economics 43, 301-339.

La Porta, R., F. Lopez-de-Silanes, A. Shleifer and R.W. Vishny (2002): Investor Protection and Corporate Valuation, Journal of Finance 57, 1147-1170.

Lee, P.M. (2001): What's in a Name.com?: The Effects of '.com' Name Changes on Stock Prices and Trading Activity, Strategic Management Journal 22, 793-804.

Liu, Y. (2010): The Valuation Effect of Corporate Name Changes: A 30-Year Perspective, European Journal of Management, Forthcoming.

Manning, Selvage \& Lee (1985): A Nationwide Survey on Corporate Names, New York, NY. 
Mase, B. (2009): The Impact of Name Changes on Company Value, Managerial Finance 35, 316-324.

McCahery, J. and A. Schwienbacher (2010): Bank Reputation in the Private Debt Market, Journal of Corporate Finance 16, 498-515.

McConnell, J.J. and H. Servaes (1990): Additional Evidence on Equity Ownership and Corporate Value, Journal of Financial Economics 27, 595-613.

McGuire, J., A. Sundgren and T. Schneeweiss (1988): Corporate Social Responsibility and Firm Financial Performance, Academy of Management Journal 31, 854-872.

McQuade, W. (1984): Cosmetic Surgery for the Company Name, Fortune Magazine, April 30, 1984.

Morck, R., A. Shleifer and R.W. Vishny (1988): Management Ownership and Market Valuation - An Empirical Analysis, Journal of Financial Economics 20, 293-315.

Office for Harmonization in the Internal Market (2010): Statistics of Community Trade Marks 2010, available at: http://oami.europa.eu/ows/rw/pages/OHIM/statistics.en.do, September 15, 2010.

Patell, J.M. (1976): Corporate Forecasts of Earnings per Share and Stock Price Behavior: Empirical Test, Journal of Accounting Research 14, 246-276.

Renneboog, L., T. Simons and M. Wright (2007): Why Do Public Firms Go Private in the UK? The Impact of Private Equity Investors, Incentive Realignment and Undervaluation, Journal of Corporate Finance 13, 591-628.

Riordan, C., R. Gatewood and J. Bill (1997): Corporate Image: Employee Reactions and Implications for Managing Corporate Social Performance, Journal of Business Ethics 16, 401-412.

Shleifer, A. and R.W. Vishny (1986): Large Shareholders and Corporate Control, Journal of Political Economy 94, 461-488.

Shleifer, A. and R.W. Vishny (1997): A Survey of Corporate Governance, Journal of Finance 52, 737-783.

Spence, M. (1973): Job Market Signaling, Quarterly Journal of Economics 87, 355-374.

Tadelis, S. (1999): What's in a Name? Reputation as a Tradable Asset, American Economic Review 89, 548-563.

Treadwell, D.F. (2003): Can Your Institution's Name Influence Constituent Response? An Initial Assessment of Consumer Response to College Names, Public Relations Review 29, 185-197. 
Weir, C., D. Laing and P.J. McKnight (2002): Internal and External Governance Mechanisms: Their Impact on the Performance of Large UK Public Companies, Journal of Business Finance and Accounting 29, 579-611.

White, H. (1980): A Heteroskedasticity-Consistent Covariance Matrix Estimator and a Direct Test for Heteroskedasticity, Econometrica 48, 817-838.

Wu, Y. (2010): What's in a Name? What Leads a Firm to Change its Name and What the New Name Foreshadows, Journal of Banking and Finance 34, 1344-1359.

Yang, S.-A., R. Fok and Y. Chang (2008): The Wealth Effects of Oil-Related Name Changes on Stock Prices: Evidence from the U.S. and Canadian Stock Markets, Working Paper University of Wisconsin-Parkside and National Chengchi University (Taiwan). 


\section{Table 1: An Overview of the Short-Term Wealth Effects of Corporate Name Changes}

This table provides an overview of the main studies (all for the U.S.) that investigate the short-term wealth effects of announcements of corporate name changes. Letters $a$ and $b$ denote significance at the $1 \%$ and $5 \%$ level, respectively. The asterisk $(*)$ denotes studies that do not consider corporate name changes in general, but announcements of special types of name changes such internet-related name changes (e.g. dotcom inclusions).

\begin{tabular}{lcrcr}
\hline Study & Period & N & CAR & Pre-event run-ups \\
\hline Howe (1982) & $1962-1980$ & 121 & $\sim 0$ [weekly returns] \\
Horsky and Swyngedouw (1987) & $1981-1985$ & 58 & $0.6^{b}[0]$ & $12.0[-30,0]$ \\
Bosch and Hirschey (1989) & $1979-1986$ & 79 & $0.5[0]$ & $2.3^{b}[-10,0]$ \\
Karpoff and Rankine (1994) & $1979-1987$ & 147 & $0.4[-1,0]$ & $4.8^{b}[-30,-2]$ \\
Lee (2001)* & $1995-1999$ & 56 & $2.7^{a}[-1,1]$ & not reported \\
Cooper et al. (2001)* & $1998-1999$ & 95 & $18.0^{a}[0,1]$ & $31.0^{a}[-15,-2]$ \\
Cooper et al. (2005)* & $1998-2001$ & 61 & $8.3^{a}[0,1]$ & $58.0^{a}[-15,2]$ \\
Yang et al. (2009)* & $2000-2007$ & 114 & $5.9[0]$ & $5.4[-15,-1]$ \\
Liu (2010) & $1978-2008$ & 4,287 & $1.2^{a}[0]$ & $3.3^{a}[-60,-2]$ \\
Wu (2010) & $1980-2000$ & 1,932 & $1.4^{a}[-1,0]$ & $1.9^{a}[-3,0]$ \\
\hline
\end{tabular}

Table 2: Summary of Sample Statistics

\begin{tabular}{lrlr}
\hline Attribute & \% of sample & Attribute & Median \\
\hline Major name changes & $56.5 \%$ & Firm age (from IPO) & 7.1 yrs. \\
Artificial name changes & $23.2 \%$ & Leverage (debt/total assets) & $58.2 \%$ \\
Service firms & $60.9 \%$ & Net income/Total assets & $1.5 \%$ \\
Firms in internet industry & $7.2 \%$ & FCF/Total assets & $4.9 \%$ \\
Firms with family names & $8.7 \%$ & $\%$ held by largest shareholder & $35.9 \%$ \\
CEO turnover 1year prior & $10.1 \%$ & $\%$ held by 2 $2^{\text {nd }}$ largest shareholder & $7.0 \%$ \\
Managerial participation & $43.5 \%$ & Free float & $38.0 \%$ \\
Free-cash-flow negative & $27.5 \%$ & No. of blockholders & 2 \\
\hline
\end{tabular}


Table 3: Description of Key Analyses Variables

\begin{tabular}{|c|c|}
\hline Variable & Definition \\
\hline Cash & $\begin{array}{l}\text { The firm's cash and cash equivalents relative to the firm's total } \\
\text { assets of the same fiscal year. }\end{array}$ \\
\hline CEO turnover & $\begin{array}{l}\text { Indicator variable that obtains a value of one if the firm's CEO } \\
\text { was replaced in the year of the name-change announcement or } \\
\text { the year prior, zero otherwise. }\end{array}$ \\
\hline CS_X and LS_X & $\begin{array}{l}\text { Indicator variable that obtains a value of one if the firm's } \\
\text { controlling shareholder (CS) (owning a block of at least } 25 \% \text { ) } \\
\text { or the largest shareholder (LS) is one of the following (X): } \\
\text { a private equity investor (incl. VC investors), an institutional } \\
\text { investor (i.e. a bank, insurance or investment company), a } \\
\text { corporation, a family, the management or others such as } \\
\text { foreign investors or employees. }\end{array}$ \\
\hline Earnings negative & $\begin{array}{l}\text { Indicator variable that obtains a value of one if the firm } \\
\text { reported a negative net income in the year prior to the name- } \\
\text { change announcement, zero otherwise. }\end{array}$ \\
\hline Family Name & $\begin{array}{l}\text { Indicator variable that obtains a value of one if the firm has a } \\
\text { family name prior to the name change, zero otherwise. }\end{array}$ \\
\hline FCF negative & $\begin{array}{l}\text { Indicator variable that obtains a value of one if the firm was } \\
\text { free-cash-flow negative in the year prior to the name-change } \\
\text { announcement, zero otherwise. }\end{array}$ \\
\hline FCF & $\begin{array}{l}\text { The firm's free cash flow standardized by the firm's total assets } \\
\text { of the same fiscal year. FCF is defined as net income plus } \\
\text { depreciation and amortization ("bankers' cash flow"). }\end{array}$ \\
\hline Herfindahl & $\begin{array}{l}\text { The Herfindahl index (sum of squared ownership shares) } \\
\text { measuring the shareholder ownership concentration. }\end{array}$ \\
\hline $\log$ Total Assets & $\begin{array}{l}\text { The natural logarithm of the firm's total assets in the year prior } \\
\text { to the name-change announcement. }\end{array}$ \\
\hline Major & $\begin{array}{l}\text { Indicator variable that obtains a value of one if the firm } \\
\text { conducts a major name change, zero otherwise. }\end{array}$ \\
\hline Managerial Ownership & The percentage of voting rights held by the firm's management. \\
\hline No. of Blockholders & $\begin{array}{l}\text { The number of shareholders owning at least a block of } 5 \% \text { of } \\
\text { the firm's stock. }\end{array}$ \\
\hline ROA & $\begin{array}{l}\text { The firm's return on assets in the year prior to the name-change } \\
\text { announcement. }\end{array}$ \\
\hline Service Firm & $\begin{array}{l}\text { Indicator variable that obtains a value of one if the firm is a } \\
\text { service firm, zero otherwise. }\end{array}$ \\
\hline \% Largest Shareholder & $\begin{array}{l}\text { The percentage of voting rights held by the firm's largest } \\
\text { shareholder. }\end{array}$ \\
\hline
\end{tabular}


Table 4: Results of the Short-Term Event Study

Asterisks denote statistical significance at the $0.01(* * *), 0.05(* *)$ and $0.10(*)$-level.

\begin{tabular}{cccccc}
\hline Window & CAAR & Patell Z & p-value & BMP & p-value \\
\hline$[-20,0]$ & 0.0439 & $3.2229^{* * *}$ & 0.0013 & $2.5296^{* *}$ & 0.0114 \\
{$[0]$} & 0.0033 & $2.4059^{* *}$ & 0.0161 & $1.8889^{*}$ & 0.0589 \\
{$[0,20]$} & -0.0128 & 1.3615 & 0.1734 & 1.1326 & 0.2574 \\
{$[-20,20]$} & 0.0278 & $2.9052^{* * *}$ & 0.0037 & $2.2999^{* *}$ & 0.0215 \\
\hline
\end{tabular}

Figure 1: Short-Term Wealth Effects - Major versus Minor Name Changes

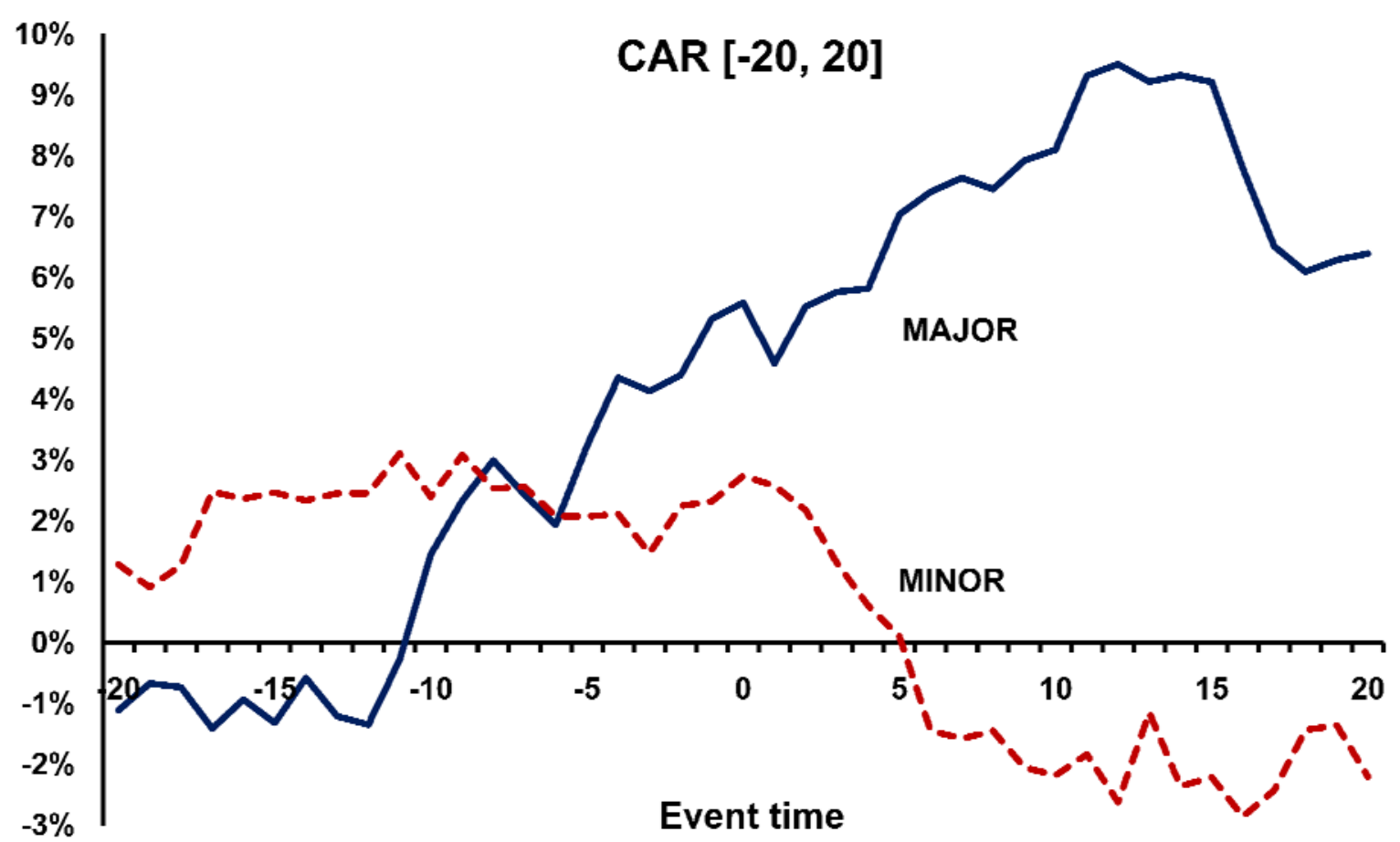


Table 5: Results of the Long-Term Event Study

Asterisks denote statistical significance at the $0.01(* * *), 0.05(* *)$ and $0.10(*)$-level, t denotes the event month.

\begin{tabular}{cccc}
\hline Window & ABHAR & t-statistic & negative \\
\hline$[\mathrm{t}-12, \mathrm{t}-1]$ & $-7.6 \%$ & -0.866 & $66 \%$ \\
{$[\mathrm{t}+1, \mathrm{t}+12]$} & $-16.4 \%^{* *}$ & -2.392 & $72 \%$ \\
{$[\mathrm{t}-12, \mathrm{t}+12]$} & $-17.9 \%^{* * *}$ & -2.995 & $72 \%$ \\
{$[\mathrm{t}+1, \mathrm{t}+6]$} & $-15.8 \%^{* * *}$ & -3.701 & $70 \%$ \\
\hline
\end{tabular}

Figure 2: Average Stock Performance around Major and Minor Name Changes

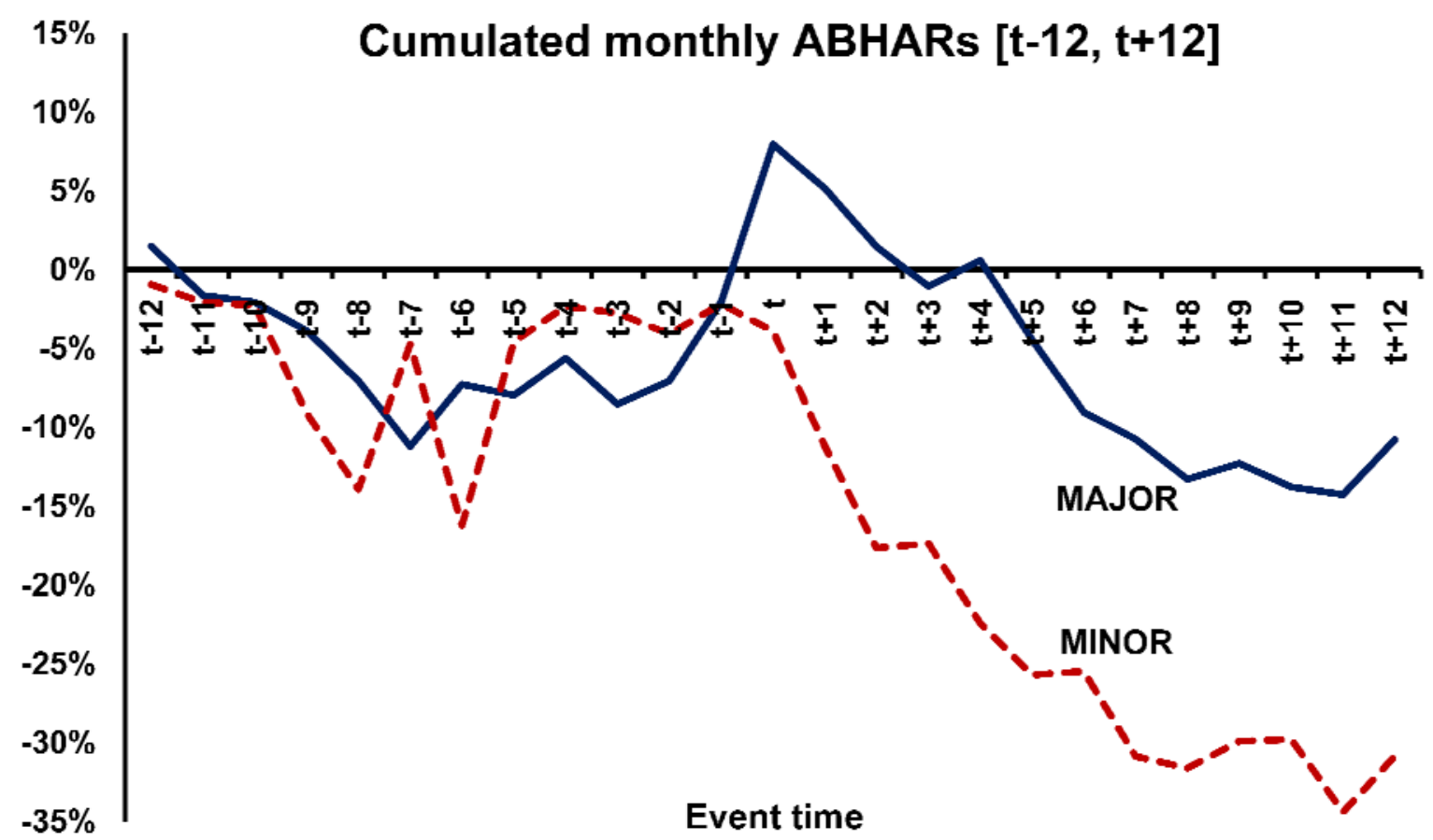




\section{Table 6: Multivariate Regression Results for Observed Short-Run Abnormal Returns}

This table contains results of OLS regressions of the firm's day-zero abnormal returns $\left(\mathrm{AR}_{\mathrm{i}}\right)$. The number of observations is 69 in all regressions. All variables are defined as explained in Table 2. A constant term (not reported) is included in all regressions. T-Statistics (in parentheses) are based on White-Heteroskedasticity consistent standard errors. Asterisks denote significance at the $0.01(* * *), 0.05(* *)$ and $0.10(*)$-level.

\begin{tabular}{|c|c|c|c|c|c|c|}
\hline Variables & (1) & (2) & (3) & (4) & (5) & (6) \\
\hline Service firm & $\begin{array}{l}-0.001 \\
(-0.12)\end{array}$ & $\begin{array}{l}-0.001 \\
(-0.05)\end{array}$ & $\begin{array}{l}-0.004 \\
(-0.29)\end{array}$ & $\begin{array}{l}0.004 \\
(0.32)\end{array}$ & $\begin{array}{l}0.002 \\
(0.15)\end{array}$ & $\begin{array}{l}0.001 \\
(0.05)\end{array}$ \\
\hline Family name & $\begin{array}{l}-0.011 \\
(-0.58)\end{array}$ & $\begin{array}{l}-0.013 \\
(-0.73)\end{array}$ & $\begin{array}{l}-0.015 \\
(-0.93)\end{array}$ & $\begin{array}{l}-0.026 \\
(-1.37)\end{array}$ & $\begin{array}{c}-0.034 \\
(-2.07)^{* *}\end{array}$ & $\begin{array}{c}-0.038 \\
(-2.50)^{* *}\end{array}$ \\
\hline log total assets & $\begin{array}{l}-0.001 \\
(-0.27)\end{array}$ & $\begin{array}{l}-0.001 \\
(-0.65)\end{array}$ & $\begin{array}{l}0.001 \\
(0.46)\end{array}$ & $\begin{array}{l}-0.001 \\
(-0.43)\end{array}$ & $\begin{array}{l}0.001 \\
(0.28)\end{array}$ & $\begin{array}{l}0.000 \\
(0.11)\end{array}$ \\
\hline Major & $\begin{array}{l}0.007 \\
(0.70)\end{array}$ & $\begin{array}{l}0.006 \\
(0.57)\end{array}$ & $\begin{array}{l}0.011 \\
(0.47)\end{array}$ & $\begin{array}{l}-0.006 \\
(-0.40)\end{array}$ & $\begin{array}{l}-0.009 \\
(-0.56)\end{array}$ & $\begin{array}{l}-0.012 \\
(-0.73)\end{array}$ \\
\hline CEO turnover & $\begin{array}{l}-0.009 \\
(-0.61)\end{array}$ & $\begin{array}{l}-0.017 \\
(-1.27)\end{array}$ & $\begin{array}{l}-0.015 \\
(-0.91)\end{array}$ & $\begin{array}{l}-0.009 \\
(-0.44)\end{array}$ & & \\
\hline Managerial ownership & & & $\begin{array}{l}-0.005 \\
(-0.16)\end{array}$ & & & \\
\hline No. of blockholders & & & $\begin{array}{l}0.000 \\
(0.02)\end{array}$ & $\begin{array}{l}-0.002 \\
(-0.69)\end{array}$ & $\begin{array}{l}-0.000 \\
(-0.10)\end{array}$ & $\begin{array}{l}-0.000 \\
(-0.05)\end{array}$ \\
\hline Herfindahl & & & $\begin{array}{l}0.021 \\
(1.21)\end{array}$ & & $\begin{array}{l}0.016 \\
(0.90)\end{array}$ & $\begin{array}{l}0.019 \\
(0.96)\end{array}$ \\
\hline \% largest shareholder & & & & $\begin{array}{l}-0.007 \\
(-0.30)\end{array}$ & & \\
\hline LS_Family & & & & $\begin{array}{c}0.046 \\
(1.82)^{*}\end{array}$ & $\begin{array}{c}0.055 \\
(2.38)^{* *}\end{array}$ & $\begin{array}{c}0.064 \\
(2.80)^{* * *}\end{array}$ \\
\hline LS_Corporate & & & & $\begin{array}{l}0.035 \\
(1.35)\end{array}$ & $\begin{array}{c}0.039 \\
(1.78)^{*}\end{array}$ & $\begin{array}{c}0.043 \\
(2.01)^{* *}\end{array}$ \\
\hline LS_Management & & & & $\begin{array}{l}0.023 \\
(0.98)\end{array}$ & $\begin{array}{c}0.038 \\
(1.83)^{*}\end{array}$ & $\begin{array}{c}0.050 \\
(2.36)^{* *}\end{array}$ \\
\hline LS_ Private Equity & & & & $\begin{array}{l}-0.003 \\
(-0.12)\end{array}$ & $\begin{array}{l}0.004 \\
(0.17)\end{array}$ & $\begin{array}{l}0.015 \\
(0.61)\end{array}$ \\
\hline LS_Institutional & & & & $\begin{array}{l}0.035 \\
(1.46)\end{array}$ & $\begin{array}{c}0.038 \\
(1.79)^{*}\end{array}$ & $\begin{array}{c}0.044 \\
(2.02)^{* *}\end{array}$ \\
\hline FCF & $\begin{array}{c}0.038 \\
(3.95)^{* * *}\end{array}$ & & $\begin{array}{c}0.034 \\
(2.92)^{* * *}\end{array}$ & $\begin{array}{c}0.045 \\
(2.98)^{* * *}\end{array}$ & $\begin{array}{c}0.043 \\
(3.04)^{* * *}\end{array}$ & \\
\hline ROA & & $\begin{array}{c}0.074 \\
(1.90)^{*}\end{array}$ & & & & $\begin{array}{c}0.080 \\
(2.23)^{* *}\end{array}$ \\
\hline Cash & $\begin{array}{l}-0.035 \\
(-0.96)\end{array}$ & $\begin{array}{l}-0.040 \\
(-1.09)\end{array}$ & & $\begin{array}{l}-0.029 \\
(-0.77)\end{array}$ & & \\
\hline Adjusted R-squared & 0.1210 & 0.0986 & 0.1092 & 0.2365 & 0.2279 & 0.1963 \\
\hline F-statistic (p-value) & 0.0068 & 0.2761 & 0.0210 & 0.0894 & 0.0389 & 0.0605 \\
\hline
\end{tabular}




\section{Table 7: Results of the Binomial Logit Regressions}

This table contains results of logit regressions. The dependent variable is the indicator variable 'Major'. The number of observations is 69 in all regressions. All variables are defined as explained in Table 2. Each regression includes a constant term (not reported). Z-Statistics are in parentheses. Asterisks denote significance at the $0.01\left({ }^{* * *}\right), 0.05\left({ }^{* *}\right)$ and $0.10(*)$-level.

\begin{tabular}{|c|c|c|c|c|c|c|}
\hline Variables & (1) & (2) & (3) & (4) & (5) & (6) \\
\hline Service firm & $\begin{array}{l}-0.318 \\
(-0.53)\end{array}$ & $\begin{array}{l}-0.475 \\
(-0.73)\end{array}$ & $\begin{array}{l}-0.199 \\
(-0.32)\end{array}$ & $\begin{array}{l}-0.601 \\
(-0.92)\end{array}$ & $\begin{array}{l}-0.611 \\
(-0.95)\end{array}$ & $\begin{array}{l}0.100 \\
(0.15)\end{array}$ \\
\hline Family name & $\begin{array}{l}-1.394 \\
(-1.27)\end{array}$ & $\begin{array}{l}-1.803 \\
(-1.50)\end{array}$ & $\begin{array}{l}-1.369 \\
(-1.24)\end{array}$ & $\begin{array}{l}-1.386 \\
(-1.25)\end{array}$ & $\begin{array}{l}-0.985 \\
(-0.96)\end{array}$ & $\begin{array}{c}-2.113 \\
(-1.82)^{*}\end{array}$ \\
\hline log total assets & $\begin{array}{l}-0.024 \\
(-0.19)\end{array}$ & $\begin{array}{l}-0.002 \\
(-0.02)\end{array}$ & $\begin{array}{l}-0.022 \\
(-0.17)\end{array}$ & $\begin{array}{l}-0.102 \\
(-0.88)\end{array}$ & $\begin{array}{l}-0.073 \\
(-0.62)\end{array}$ & $\begin{array}{l}-0.043 \\
(-0.27)\end{array}$ \\
\hline CEO turnover & $\begin{array}{l}0.607 \\
(0.65)\end{array}$ & $\begin{array}{l}1.146 \\
(1.01)\end{array}$ & $\begin{array}{l}1.561 \\
(1.47)\end{array}$ & $\begin{array}{l}0.687 \\
(0.68)\end{array}$ & $\begin{array}{l}0.604 \\
(0.60)\end{array}$ & $\begin{array}{l}0.830 \\
(0.82)\end{array}$ \\
\hline Managerial ownership & & $\begin{array}{l}1.509 \\
(1.26)\end{array}$ & $\begin{array}{l}1.824 \\
(1.56)\end{array}$ & $\begin{array}{l}0.547 \\
(0.51)\end{array}$ & $\begin{array}{l}1.048 \\
(0.99)\end{array}$ & \\
\hline No. of blockholders & & $\begin{array}{c}-0.440 \\
(-1.93)^{*}\end{array}$ & $\begin{array}{c}-0.345 \\
(-1.66)^{*}\end{array}$ & $\begin{array}{c}-0.472 \\
(-2.09) * *\end{array}$ & $\begin{array}{c}-0.369 \\
(-1.78)^{*}\end{array}$ & \\
\hline Herfindahl & & $\begin{array}{l}-0.971 \\
(-0.82)\end{array}$ & $\begin{array}{l}-1.507 \\
(-1.30)\end{array}$ & & & \\
\hline \% largest shareholder & & & & $\begin{array}{l}-0.118 \\
(-0.10)\end{array}$ & $\begin{array}{l}-0.494 \\
(-0.43)\end{array}$ & $\begin{array}{l}1.320 \\
(1.11)\end{array}$ \\
\hline LS_Family & & & & & & $\begin{array}{l}1.960 \\
(1.55)\end{array}$ \\
\hline LS_Corporate & & & & & & $\begin{array}{l}0.431 \\
(0.38)\end{array}$ \\
\hline LS_Management & & & & & & $\begin{array}{c}2.276 \\
(1.81)^{*}\end{array}$ \\
\hline LS_Private Equity & & & & & & $\begin{array}{l}-0.857 \\
(-0.73)\end{array}$ \\
\hline LS_ Institutional & & & & & & $\begin{array}{l}1.936 \\
(1.50)\end{array}$ \\
\hline FCF negative & $\begin{array}{c}1.433 \\
(2.06)^{* *}\end{array}$ & $\begin{array}{c}1.729 \\
(2.14)^{* *}\end{array}$ & & $\begin{array}{c}1.919 \\
(2.36)^{* *}\end{array}$ & & \\
\hline Earnings negative & & & & & $\begin{array}{c}1.374 \\
(2.03)^{* *}\end{array}$ & \\
\hline ROA & & & $\begin{array}{l}-1.613 \\
(-0.68)\end{array}$ & & & \\
\hline Cash & $\begin{array}{l}2.437 \\
(1.60)\end{array}$ & $\begin{array}{l}2.517 \\
(1.45)\end{array}$ & $\begin{array}{l}2.469 \\
(1.47)\end{array}$ & & & $\begin{array}{c}3.389 \\
(1.79)^{*}\end{array}$ \\
\hline Pseudo R-squared & 0.1183 & 0.1938 & 0.1427 & 0.1564 & 0.1321 & 0.2344 \\
\hline Wald Chi-squared (p-value) & 0.0831 & 0.0317 & 0.1418 & 0.0636 & 0.1311 & 0.0233 \\
\hline
\end{tabular}


Table 8

Pairwise Correlations

\begin{tabular}{|c|c|c|c|c|c|c|c|c|c|c|c|c|c|c|c|c|c|c|c|c|c|}
\hline & Leverage & Major & $\begin{array}{l}\text { Prior } \\
\text { stock } \\
\text { perform }\end{array}$ & log Age & $\begin{array}{l}\text { Service } \\
\text { firm }\end{array}$ & $\begin{array}{l}\text { No. of } \\
\text { blockhol } \\
\text { ders }\end{array}$ & $\begin{array}{l}\text { Man. } \\
\text { particip } \\
\text { ation }\end{array}$ & $\log \mathrm{TA}$ & ROA & $\begin{array}{l}\mathrm{FCF} / \\
\mathrm{TA}\end{array}$ & $\begin{array}{l}\text { Cash / } \\
\text { TA }\end{array}$ & $\begin{array}{l}\text { FCF } \\
\text { negative }\end{array}$ & $\begin{array}{l}\text { Family } \\
\text { name }\end{array}$ & $\begin{array}{l}\text { Herfind } \\
\text { ahl }\end{array}$ & $\begin{array}{l}\text { Man. } \\
\text { Owner- } \\
\text { ship }\end{array}$ & $\begin{array}{l}\text { LS_ } \\
\text { Family }\end{array}$ & $\begin{array}{l}\text { LS_ } \\
\text { Manage } \\
\text { ment }\end{array}$ & $\begin{array}{l}\mathrm{LS}_{-} \\
\text {Corpora } \\
\text { te }\end{array}$ & $\begin{array}{l}\text { LS_ } \\
\text { Private } \\
\text { equity }\end{array}$ & $\begin{array}{l}\mathrm{LS}_{-} \\
\text {Instituti } \\
\text { onal }\end{array}$ & $\begin{array}{l}\text { LS_ } \\
\text { Others }\end{array}$ \\
\hline Major & -0.22 & 1.00 & & & & & & & & & & & & & & & & & & & \\
\hline Prior stock performance & 0.02 & 0.20 & 1.00 & & & & & & & & & & & & & & & & & & \\
\hline log Age & 0.49 & -0.07 & -0.10 & 1.00 & & & & & & & & & & & & & & & & & \\
\hline Service firm & -0.34 & 0.08 & 0.03 & -0.43 & 1.00 & & & & & & & & & & & & & & & & \\
\hline No. of blockholders & 0.33 & -0.24 & -0.08 & 0.21 & -0.20 & 1.00 & & & & & & & & & & & & & & & \\
\hline Man. participation & -0.08 & 0.15 & 0.10 & -0.16 & 0.14 & -0.05 & 1.00 & & & & & & & & & & & & & & \\
\hline $\log \mathrm{TA}$ & 0.65 & -0.16 & 0.00 & 0.48 & -0.39 & 0.15 & -0.20 & 1.00 & & & & & & & & & & & & & \\
\hline ROA & 0.22 & -0.10 & 0.02 & 0.35 & -0.21 & -0.17 & -0.12 & 0.14 & 1.00 & & & & & & & & & & & & \\
\hline FCF / TA & 0.18 & -0.15 & -0.05 & 0.18 & -0.10 & -0.10 & -0.08 & -0.01 & 0.51 & 1.00 & & & & & & & & & & & \\
\hline Cash / TA & -0.55 & 0.24 & 0.03 & -0.49 & 0.23 & -0.23 & -0.16 & -0.58 & -0.06 & -0.08 & 1.00 & & & & & & & & & & \\
\hline FCF negative & -0.23 & 0.28 & -0.05 & -0.33 & 0.23 & 0.14 & 0.07 & -0.22 & -0.69 & -0.48 & 0.16 & 1.00 & & & & & & & & & \\
\hline Family name & -0.15 & -0.04 & -0.08 & -0.13 & -0.07 & 0.01 & 0.15 & -0.24 & 0.00 & -0.04 & 0.22 & 0.16 & 1.00 & & & & & & & & \\
\hline Herfindahl & -0.05 & -0.03 & 0.00 & 0.22 & 0.17 & -0.34 & 0.02 & -0.16 & 0.25 & 0.18 & 0.00 & -0.25 & 0.07 & 1.00 & & & & & & & \\
\hline Man. Ownership & 0.01 & 0.08 & 0.02 & -0.06 & 0.02 & -0.19 & 0.67 & -0.13 & -0.03 & -0.10 & -0.21 & -0.04 & 0.12 & 0.41 & 1.00 & & & & & & \\
\hline LS_Family & -0.22 & 0.17 & 0.10 & -0.15 & 0.05 & 0.00 & 0.11 & -0.04 & -0.11 & -0.07 & 0.08 & 0.15 & 0.19 & -0.09 & -0.06 & 1.00 & & & & & \\
\hline LS_Management & 0.08 & 0.17 & -0.14 & -0.15 & -0.02 & 0.04 & 0.54 & -0.14 & -0.19 & -0.01 & -0.10 & 0.15 & 0.13 & -0.23 & 0.28 & -0.18 & 1.00 & & & & \\
\hline LS_Corporate & 0.08 & -0.08 & -0.09 & 0.28 & -0.20 & -0.14 & -0.10 & 0.00 & 0.23 & 0.04 & -0.10 & -0.07 & 0.05 & 0.35 & 0.12 & -0.23 & -0.27 & 1.00 & & & \\
\hline LS_Private equity & -0.09 & -0.28 & 0.02 & -0.14 & 0.26 & -0.03 & -0.21 & -0.17 & 0.05 & 0.23 & 0.05 & -0.15 & -0.16 & 0.01 & -0.24 & -0.20 & -0.23 & -0.30 & 1.00 & & \\
\hline LS_Institutional & 0.11 & 0.17 & -0.07 & 0.10 & -0.04 & 0.14 & -0.24 & 0.26 & -0.13 & -0.16 & 0.03 & 0.05 & -0.12 & -0.17 & -0.23 & -0.15 & -0.18 & -0.23 & -0.20 & 1.00 & \\
\hline LS_Others & 0.03 & -0.09 & 0.24 & 0.01 & -0.03 & 0.03 & -0.09 & 0.15 & 0.10 & -0.09 & 0.08 & -0.10 & -0.10 & 0.07 & 0.11 & -0.13 & -0.15 & -0.20 & -0.17 & -0.13 & 1.00 \\
\hline \% largest shareholder & -0.13 & 0.05 & 0.06 & 0.13 & 0.13 & -0.43 & 0.02 & -0.18 & 0.25 & 0.24 & 0.05 & -0.28 & 0.11 & 0.90 & 0.38 & -0.03 & -0.19 & 0.42 & -0.06 & -0.18 & -0.06 \\
\hline
\end{tabular}

